\title{
Turkish Science Student Teachers' Conceptions on the States of Matter
}

\author{
Abdullah Aydın ${ }^{1} \&$ Yasemin Gödek Altuk ${ }^{2}$ \\ ${ }^{1}$ Faculty of Education, Department of Science Teacher Education, Ahi Evran University, Kırşehir, Turkey \\ ${ }^{2}$ Ministry of Youth and Sports, Ankara, Turkey \\ Correspondence: Abdulah Aydın, Eğitim Fakültesi, Fen Bilgisi Öğretmenliği Anabilim Dalı, Ahi Evran \\ Üniversitesi, Terme Cad., Kırşehir, Turkey. Tel: 90-505-487-4471. E-mail: aaydinch@gmail.com
}

Received: January 16, 2013 Accepted: January 28, 2013 Online Published: April 28, 2013

doi:10.5539/ies.v6n5p104 URL: http://dx.doi.org/10.5539/ies.v6n5p104

\begin{abstract}
This study aims to determine science students teachers' conceptions on the concepts related to 'the matter and the states of the matter'. 112 Turkish science student teachers participated at this research. A questionnaire consisting of thirteen open-ended items was designed to collect the data. The questionnaire aimed to reveal the students' views concerning; the features of 'solid, liquid and gas' states and their application in everyday life, the state of matter at room temperature and in normal conditions, the particulate structure of matter, unique properties of each particle of matter, the relationship between the force of attraction between these particles and room temperature. The results were analyzed mainly qualitatively, but also quantitatively. As an outcome of the analysis, fourteen misconceptions were determined. These misconceptions can be categorized as 'mentioning of the state of matter without specifying the temperature and the pressure', 'not comprehending that liquids evaporate at any temperature', 'not understanding the features of the particulate structures of solid, liquid and gas substances (volume and the number of the particles)'.
\end{abstract}

Keywords: chemistry education, misconceptions, the states of matter

\section{Introduction}

It seems inconsistent with the nature of human beings, living without being informed about the flow of the events in the universe. Therefore, since the existence of humanity, the conditions in which this great wheel turns, conclusions to be and have been generated, have been the subject of curiosity and with this, drove humanity to conduct research. With the help of developing technologies, new information can be reached on many issues (Birinci Konur \& Ayas, 2008).

Objects, events, people and ideas are grouped according to their similarities, whereby the names given to these groups are called 'concepts' which at the other hand are the building blocks of new information (Kaptan, 1998). Research results show that target concepts aimed to be entitled to students in science education, are not always resulted in a meaningful learning (Erdem, et al., 2004). From primary education to university; no matter at which level the students are, they have difficulties in understanding some of the concepts. It is known that, as a result of misunderstandings students have misconceptions, while due to the applied rote learning, concepts are not permanently memorized (Karaer, 2007).

In learning process, students establish a relationship between the events that affect their lives and the information gained at school (Karamustafaoğlu \& Ayas, 2005). However, research on science education point out that students perceive many scientific concepts different than the scientifically accepted views (Haidar \& Abraham, 1991). This perception is called as 'alternative framework' (Driver et al., 1978; Watts, 1983), 'misconception' (Helm, 1980; Lawson \& Thompson, 1988; Treagust, 1988; Janiuk, 1993, Chou, 2002; Özmen \& Ayas, 2003) 'children's science' (Gilbert et al., 1982) or 'alternative conception' (Gilbert et al., 1985). This study will use the term 'misconception', thus it is the commonly used one in Turkey, whilst the study itself has been conducted in Turkey.

It is also known that the misconceptions absorbed by the minds of the students, will after a certain time lead to a blockage of future learning (Tunç, et al., 2011). For this reason, science educators have been conducting research on the issues of misconceptions and conceptual change (Coştu, et al., 2007). Different models of conceptual change have been suggested by researchers (Posner et al., 1982, Strike \& Posner, 1992, Duit \& Treagust, 2003, Gregoire, 2003). 
In Turkey, for only the last two decades, studies aimed to reveal students' misconceptions in the concepts of chemistry, physics and biology, such as; acids \& bases (Üce \& Sarıçayır, 2002; Çetingül \& Geban, 2005; Özmen \& Demircioğlu, 2003; Özmen \& Yıldırım, 2005); atom (Tezcan \& Salmaz, 2005); gravity (Küçük, 2005); radioactivity (Yalçın \& Kılıç, 2005); boiling (Coştu et al., 2007; Buluş Kırıkkaya \& Güllü, 2008); condensation (Boz, 2005); chemical bonding (Atasoy et al., 2003; Pabuçcu \& Geban, 2006); covalent bonding (Öztürk Ürek \& Tarhan, 2005; Ünal et al., 2010); ionic bonding (Ayar Kayalı \& Tarhan, 2004); diffusion (Yıldırım et al., 2004); diffusion and osmosis (Tekkaya, 2003); dissolving (Gödek, 1997; Gödek, 2004; Tezcan \& Bilgin, 2004; Tezcan \& Yılmazel, 2004; Çalık \& Ayas, 2005; Çalık et al., 2006; Koray et al., 2007; Şen \& Y1lmaz, 2012); electric current (Çıldır \& Şen, 2006; Yıldırım et al., 2008); electric circuits (Sencar et al., 2001; Küçüközer, 2003; Ateş \& Polat, 2005; Küçüközer \& Kocakülah, 2007; Kaya \& Gödek Altuk, 2010); static electricity concepts (Başer \& Geban, 2007); energy (Ünal Çoban et al., 2007; Hırça et al., 2008); force (Kurt \& Akdeniz, 2004); force and motion (Yıldız \& Büyükkasap, 2006); chemical change and conservation of matter (Geban \& Bayır, 2000); chemical equilibrium (Sepet et al., 2004); evaporation (Buluş Kırıkkaya \& Güllü, 2008); heat and temperature (Aydoğan et al., 2003; Başer \& Çataloğlu, 2005; Buluş Kırıkkaya \& Güllü, 2008); mass and weight (Koray et al., 2005); matter (Erdem et al., 2004); light, vision and mirrors (Şen, 2003); structure and conductivity of mixtures (Akgün et al., 2005); substance (Karaer, 2007); physical and chemical changes (Atasoy et al., 2007); reaction rate and its relationship with concentration or pressure (Çakmakçı et al., 2006); radioactivity (Yalçın \& Kılıç, 2005); sound (Demirci \& Efe, 2007); earth and the universe (Baloğlu Uğurlu, 2005); respiration and anaerobic respiration (Yürük \& Çakır, 2000); genetics (Tatar \& Cansüngü Koray, 2005; Topçu \& Şahin-Pekmez, 2009); digestion (Çakıcı, 2005); classification of living things and their diversity (Türkmen et al., 2005); photosynthesis and respiration (Tekkaya \& Balc1, 2003); photosynthesis and plant nutrition (Özay \& Öztaş, 2003); greenhouse effect (Bozkurt \& Cansüngü Koray, 2002; Arsal, 2010). In terms of the kinds of the misconceptions revealed, and their sources, the results of these studies seem to be consistent with the results of related studies in literature.

Research show that the misconceptions occur due to learner's unschooled experience of the World, media, language and models used by teachers and textbooks, culture and overgeneralizations (Driver et al., 1985, Gunstone, 1988, Coştu et al., 2007). The sources of misconceptions may also differ depending on the nature of the discipline. Most misconceptions in chemistry do not derive from the learner's unschooled experience of the World but result from the situations occurring in formal learning environment, the limitation of the models in science, mistakes in model applications and misleading expressions in the language used (Taber, 2001). The literature also supports, that the interplay between macroscopic and microscopic worlds is a source of difficulty for many chemistry learners (Sirhan, 2007).

The particulate nature of matter could be accepted as a foundation for understanding other chemistry concepts and to explain the changes in state, chemical reactions and behaviors of gases, students must have an understanding of the particulate nature of matter (Singer, et al., 2003, Özmen \& Kenan, 2007). Any meaningful study of chemistry requires learners to have grasped the notion of substance and to appreciate that substances maintain their identity through a change of state (Taber, 2001). Taber (2001) points out that even though a great deal of the theoretical structure of chemistry depends on entities that are on a molecular level (ions, electrons, orbitals, ...), the learner experiences chemistry (substances and their interactions) at a macroscopic level. Chemists tend to switch between considering these two levels when discussing their subject. Yet, this situation creates several problems for the learner (Sirhan, 2007). Accordingly, the literature of science education indicates that students have difficulties understanding the structure of matter (Ben-Zvi et al., 1986, Krajcik, 1991, Griffiths $\&$ Preston, 1992, Taber, 2001, Erdem, et al., 2004). In a comprehensive study on the structure of matter, numbers of misconceptions as listed below have been detected (Griffiths \& Preston, 1992):

- A molecule has a weighable weight.

- Atoms can be seen with a microscope.

- Water is a homogeneous mixture consisting of oxygen and hydrogen.

- Atoms and molecules have macroscopic properties.

- When matter is heated, atoms expand.

- When matter is frozen, atoms freeze too.

- Atoms or molecules comprising matter, reflect the properties of that matter (atoms could be colorful, conductive, etc.).

- All atoms have the same weight.

- Atoms and molecules move, so they are alive. 
- Matter has a continuous structure and there are no spaces between atoms and molecules.

- During a change of the state of matter, changes occur in atom's size, shape and weight.

- Under standard conditions, the volume of one mole; solid or liquid is 22,4 liter.

- All atoms or molecules of the matter move at the same speed.

- During melting and boiling, intramolecular bonds are broken.

- Bubbles in boiling water are air molecules.

- When a substance changes its state from liquid into gas, its mass is reduced.

- Gases have no mass.

Boz (2005) examined $6^{\text {th }}, 8^{\text {th }}$ and $11^{\text {th }}$ year students' misconceptions on the condensation of water vapor and found that the majority of students had difficulty in understanding this topic. In a study to find out the misconceptions regarding boiling and its reasons, teachers pointed out that their students wrongly believed that "boiling is a form of rapid evaporation" (Coştu, et al., 2007: 130). In another study on secondary school students, even though they were taught about the properties of matter and gases, believed that gases have no weight (Stavy, 1987; in Morgil, et al., 2003). In Erdem's et al., (2004) study, first year science teacher students had low levels of understanding and misconceptions particularly in the concepts of solubility, dissolving and phase change. Moreover, Tatar (2011) examined 227 fourth-year primary school students teachers' views on the states of matter and presented their misconceptions under five main headings including; weight, shape, particle, flowing and volume. On the other hand, Boz \& Boz (2011) investigated 22 chemistry student teachers' subject matter knowledge and their awareness of student's difficulties in understanding the particulate nature of matter within phase changes. They found out that most student teachers' subject matter knowledge was sufficient, but only $14 \%$ of the participants still had difficulties in applying the particulate theory, for explaining the notion of constant temperature during melting. The majority of them could think of pupils' possible difficulties about the particulate theory in the context of phase changes.

Teachers need to associate the concepts and make connections between the concepts and students' daily life. In other words; they need to translate scientific information to the students' level without juggling with the scientific meaning of information. Moreover, in the process of constructing knowledge, in order teachers can be able to identify students' misconceptions correctly and efficiently and to guide their students adequately; teachers themselves should not have those misconceptions. Therefore, in teacher education courses student teachers' possible misconceptions should be identified and teacher educators have to be aware of student teachers' misconceptions. For this reason, this study aims to determine science student teachers' misconceptions on the concepts related to 'matter and its states'.

\section{Method}

One of the methods commonly used in identifying misconceptions is interviewing (Fensham, et al., 1981). Interviewing is a form of a data collection method which "sought the answer from the people within the framework of research questions. Interviews provide in-depth knowledge about a specific research topic or a question". However, this method "as in all research methods, is open to errors and individual aptitude. Most importantly, obtaining reliable and valid results is the main difficulty of interviews". For its "training and preparation" this method takes time for the interviewer (Büyüköztürk, et al., 2008: 232). The interviewing method also limits the sample. On the other hand, open-ended questions and multiple choice questions either alone or as part of a multiple-choice questions are used to determine students' misconceptions. However, Boo's (2006) study argues that Multiple Choice Questions provide no means for the students to express their own views to those articulating the questionnaire. On the other hand, a well-structured open-ended questionnaire gives the interviewees the opportunity to express their views in their own words and reveal their higher level of thinking skills (Gronlund \& Linn, 1990; in Azizoğlu \& Alkan, 2002).

In this study, a case study approach was applied. This approach provides opportunities for in-depth research within the specific subject boundaries (Çepni, 2001).

\subsection{Sample}

This study was carried out during the academic year of 2009-2010, at spring term, in the Department of Primary Science Education in a Turkish State University. 61 (16 men \& 45 women) student teachers of day time education and 51 ( 21 men \& 30 women) science student teachers of evening education, aggregating to a total of 112 third year science student teachers participated in this research. Third-year science student teachers were chosen since they all already studied the topic of "matter and its states" in "General Chemistry I" and "Specific 
Topics in Chemistry" courses and completed all chemistry courses including "General Chemistry I-II, General Chemistry Laboratory I-II, Analytical Chemistry, Organic Chemistry, and Specific Topics in Chemistry". These student teachers were supposed to give correct answers to the questions asked due to the reasons that the topic of "matter and its states" was taught in the courses of Primary Science and Technology, Secondary School Chemistry, and in courses at university level.

\subsection{Data Collection Instruments}

A questionnaire consisting of 13 open-ended items was designed to collect the data. The questionnaire aimed to reveal student teachers' views concerning;

- The properties of the states of 'solid, liquid and gas' and their uses in everyday life,

- The state of matter at room temperature $\left(25^{\circ} \mathrm{C}\right.$ and $1 \mathrm{~atm}$.) and in normal conditions $\left(0^{\circ} \mathrm{C}\right.$ and $1 \mathrm{~atm}$.),

- Particulate structure of matter,

- Unique properties of each particle of matter,

- The relationship between attraction force among these particles and room temperature.

The validity of these questions was provided by the examination of the questions by a chemistry education expert and a science education expert. During the process of piloting, the questionnaire consisted of 15 open-ended questions. 50 student teachers participated to pilot study. In the pilot study, two questions were not adequately understood by the students, and therefore these questions were removed. Accordingly, the final version of the questionnaire contained thirteen open-ended questions.

\subsection{Data Collection}

Before the data collection, the researchers explained to student teachers that this study aims to reveal their views concerning the concepts related to 'matter and its states', and expressed that their voluntary participation is needed. Filling out the questionnaire took approximately 60-90 minutes whilst there was no time limitation.

\subsection{Data Analysis}

In the data collection tool, each question consisted of two options. One of which was for the response, the other one was for the reason of that response. For the analysis of the responses, a scientific answer key was prepared by a chemistry education expert and a science education expert. Student teachers' responses were analyzed according to this scientific answer key. During the analysis, a coding system similar to Abraham's et al., (1992) coding system was used. The compliance rate of two encoders was found to be $95 \%$. In the analysis of the responses, percentage and frequencies were used. Concisely, data were analyzed mainly qualitatively, but also quantitatively.

\section{Findings}

As a result of the analysis, in three general areas were determined (Table 1).

Table 1. Kind of misconceptions identified on 'the states of matter'

Numbers of students

Kind of misconception

$(\mathrm{N}=112)$

\begin{tabular}{|c|c|c|c|}
\hline & & & \\
\hline & & $f$ & $\%$ \\
\hline $\mathbf{A}$ & Not comprehending that liquids evaporate at any temperature & 50,0 & 44,6 \\
\hline B & $\begin{array}{l}\text { Mentioning of the state of matter without specifying the temperature and the } \\
\text { pressure and errors made in identifying the states of solid, liquid, gas }\end{array}$ & 47,6 & 42,5 \\
\hline C & $\begin{array}{l}\text { Not understanding the properties of the particulate structures of solid, liquid } \\
\text { and gaseous substances (volume and the number of the particles) }\end{array}$ & 21,0 & 18,8 \\
\hline
\end{tabular}

As presented in Table 1, 44,6 \% student teachers could not perceive that 'liquids evaporate at any temperature', and over generalized by believing that 'water vapor would convert into gas at over $100{ }^{0} \mathrm{C}$, and liquid under 100 ${ }^{0} \mathrm{C}$ '. In literature, there are studies related to students' misconceptions about condensation (Boz, 2005). Thus, 
$42,5 \%$ of student teachers 'did not mention the temperature and the pressure, in identifying the solid, liquid and gas states of the substances'. Accordingly, they had misconceptions in the identification of solid, liquid and gas states of the substances. A minor percentage of student teachers $(18,8 \%)$ could not adequately understand the properties (volume and the number of the particles) of solid, liquid and gas substances at particulate level. They seemed to unconsciously draw the pictures related to solid, liquid and gas substances at particulate level. Similar findings were found in literature (Canpolat, et al., 2004).

In the above three general areas, fourteen misconceptions were identified (Table 2).

Table 2. Misconceptions identified on 'the states of matter'

\begin{tabular}{|c|c|c|c|}
\hline \multirow[t]{2}{*}{$\begin{array}{l}\text { Kind of } \\
\text { misconception }\end{array}$} & \multirow[t]{2}{*}{ Misconceptions identified } & \multicolumn{2}{|c|}{$\begin{array}{l}\text { Numbers of } \\
\text { students } \\
(\mathrm{N}=112)\end{array}$} \\
\hline & & $\mathrm{f}$ & $\%$ \\
\hline B & $\begin{array}{l}\text { Mentioning of the state of matter, without specifying the temperature } \\
\text { and the pressure. }\end{array}$ & 79 & 70,5 \\
\hline B & $\begin{array}{l}\text { At room temperature }\left(25^{0} \mathrm{C}\right) \text { and pressure of } 1 \text { atmosphere, stating that } \\
\text { 'water vapor is liquid, cologne is gas, sponge and glass are solid'. }\end{array}$ & 74 & 66,1 \\
\hline $\mathbf{A}$ & Water vapor is gas at over $100^{\circ} \mathrm{C}$, water vapor is liquid at under $100^{\circ} \mathrm{C}$. & 66 & 58,9 \\
\hline B & $\begin{array}{l}\text { Substances are classified as solid, liquid and gas substances because } \\
\text { each substance has a unique structure. }\end{array}$ & 60 & 53,6 \\
\hline B & $\begin{array}{l}\text { At room temperature }\left(25^{0} \mathrm{C}\right) \text { and } 1 \mathrm{~atm} \text {. the reason of the substances for } \\
\text { being at different states is their temperature. }\end{array}$ & 37 & 33 \\
\hline $\mathbf{A}$ & $\begin{array}{l}\text { At normal conditions }\left(0^{0} \mathrm{C} \text { and } 1 \mathrm{~atm} \text {.) water vapor condenses and }\right. \\
\text { changes into a liquid. }\end{array}$ & 34 & 30,4 \\
\hline $\mathbf{C}$ & $\begin{array}{l}\text { When the attraction force of the particles was weakened by the energy } \\
\text { taken from the environment, and the spaces between the particles are } \\
\text { greater, the substance would be in solid state. }\end{array}$ & 29 & 25,9 \\
\hline $\mathbf{C}$ & There are no spaces between the particles of solid substances. & 26 & 23,2 \\
\hline B & $\begin{array}{l}\text { At room temperature, when the attraction force between the particles } \\
\text { are large enough not to be overcome by the energy taken from the } \\
\text { environment, the matter is at gas state. Because if it would overcome, } \\
\text { the matter would have changed its state. }\end{array}$ & 24 & 21,4 \\
\hline $\mathbf{C}$ & $\begin{array}{l}\text { The number of particles decreases while the state changes from solid } \\
\text { into gas whereby the size of the particles increase. }\end{array}$ & 21 & 18,8 \\
\hline $\mathbf{C}$ & $\begin{array}{l}\text { A solid substance is being heated while being in a closed container. } \\
\text { Accordingly the state of the substance changes. The change of the state } \\
\text { of the matter leads to a change of the size of particles. Because, when } \\
\text { the temperature increases, the volume of the particles increases, leading } \\
\text { to an enlargement of the particles. }\end{array}$ & 20 & 17,9 \\
\hline $\mathbf{C}$ & $\begin{array}{l}\text { When the attraction force of the particles has been overcome by the } \\
\text { energy taken from the environment whereby there is no relation } \\
\text { between the particles, the substance would be in solid state. When the } \\
\text { matter moves away from its environment, it would be in gas state. }\end{array}$ & 18 & 16,1 \\
\hline B & $\begin{array}{l}\text { For any substance, depending on their hardness, softness, and } \\
\text { viscosity, reaching the conclusion that they are solid, liquid or gas, } \\
\text { without specifying their temperature and pressure. }\end{array}$ & 12 & 10,7 \\
\hline $\mathbf{C}$ & $\begin{array}{l}\text { A solid substance is being heated while being in a closed container. } \\
\text { Accordingly the state of the substance changes. The change of the state } \\
\text { of the matter leads to a change of the number of particles. Because, } \\
\text { when the solid is heated, it changes into liquid, it becomes fluid, the } \\
\text { spaces between the particles increases, accordingly, the numbers of the } \\
\text { particles reduce. }\end{array}$ & 12 & 10,7 \\
\hline
\end{tabular}




\section{Results}

This study aimed to identify 112 science student teachers' misconceptions on the concepts related to 'matter and its states'. A questionnaire with 13 open-ended revealed student teachers' views concerning; the properties of the states of 'solid, liquid and gases' and their uses in everyday life while the state of the matter at room temperature $\left(25^{\circ} \mathrm{C}\right.$ and $\left.1 \mathrm{~atm}\right)$ and in normal conditions $\left(0^{\circ} \mathrm{C}\right.$ and $\left.1 \mathrm{~atm}\right)$, particulate structure of matter, unique properties of each particle of matter, the relationship between the attraction force between these particles and the room temperature. As a result of the analysis, fourteen kinds of misconceptions were determined. These misconceptions have been categorized as;

1) 'Not comprehending that liquids evaporate at any temperature',

2) 'Mentioning of the state of matter without specifying temperature and pressure',

3) 'Not understanding the properties of the particulate structures of solid, liquid and gaseous substances (volume and the number of the particles)'.

These misconceptions seem to support the view that the interplay between macroscopic and microscopic worlds is a source of difficulty for learners (Sirhan, 2007). In this study too, student teachers seem to focus at the molecular level but not at a macroscopic level. They seem to fail to switch between considering these two levels when discussing the matter and its states (Ben-Zvi et al., 1986, Krajcik, 1991, Griffiths \& Preston, 1992, Taber, 2001, Erdem, et al., 2004, Sirhan, 2007).

\section{Suggestions}

In order to overcome these misconceptions, science and technology teachers, chemistry teachers and curriculum designers should be sensitive in identifying students' misconceptions and should be aware of these misconceptions. They should know the techniques of identifying misconceptions, and develop different teaching strategies and methods to overcome misconceptions. Tsaparlis (1997) suggests teaching introductory chemistry through three cycles at the macro, representational and sub-micro levels. For instance, in Singer's et al., (2003) study, various types of representations (multiple levels of representations -macro, micro, symbolic; gumdrops, hand, human models, computerized models, eChem models and drawings) enabled students to make transitions between the macroscopic, microscopic, and symbolic levels.

Teachers can also be the source of many of the misconceptions of the pupils (Boo, 2006). As a result; pupils' misconceptions should be discussed in teacher education courses (Boz \& Boz, 2012).

Moreover, student teachers should actively participate in identifying pupils' misconceptions since it enhances student teachers' awareness concerning pupils' learning difficulties and the identification of misconceptions and therefore, seems useful in developing student teachers' knowledge base (Gödek Altuk \& Kaya, 2011). Thereby, this kind of activities will enable student teachers to face their own misconceptions.

\section{References}

Abraham, M. R., Grzybowski, E. B., Renner, J. W., \& Marek, E. A. (1992). Understanding and Misunderstanding of Eight Graders of Five Chemistry Concepts Found in Textbooks. Journal of Research in Science Teaching, 29(2), 105-120. http://dx.doi.org/10.1002/tea.3660290203

Akgün, A., Gönen, S., \& Yılmaz, A. (2005). Fen Bilgisi Öğretmen Adaylarının Karışımların Yapısı ve İletkenliği Konusundaki Kavram Yanılgıları. Hacettepe University Journal of Education, 28, 1-8.

Arsal, Z. (2010). The Greenhouse Effect Misconceptions of the Elementary School Teacher Candidates. Elementary Education Online, 9(1), 229-240. Retrieved from http://ilkogretim-online.org.tr

Atasoy, B., Genç, E., Kadayıfçı, H., \& Akkuş, H. (2007). The-effect of cooperative learning to grade 7 students' understanding of physical and chemical changes topic, Hacettepe University Journal of Education, 32, $12-21$.

Atasoy, B., Kadayıf̧̧ı, H., \& Akkuş, H. (2003). Lise 3. Sınıftaki Öğrencilerin Kimyasal Bağlar Konusundaki Yanlış Kavramaları ve Bunların Giderilmesi Üzerine Yapılandırmacı Yaklaşımın Etkisi. Türk Ĕgitim Bilimleri Dergisi, 1, 61-79.

Ateş, S., \& Polat, M. (2005). Elektrik Devreleri Konusundaki Kavram Yanılgılarının Giderilmesinde Öğrenme Evreleri Metodunun Etkisi. Hacettepe University Journal of Education, 28, 39-47.

Ayar Kayalı, H., \& Tarhan, L. (2004). İyonik Bağlar konusunda kavram yanılgılarının giderilmesi amacıyla yapılandırmacı -aktif öğrenmeye dayalı bir rehber material uygulaması. Hacettepe University Journal of Education, 27, 145-154. 
Aydoğan, S., Güneş, B., \& Gülçiçek, Ç. (2003). Isı ve Sıcaklık Konusunda Kavram Yanılgıları. Gazi University Journal of Gazi Educational Faculty, 23(2), 111-124.

Azizoğlu, N., \& Alkan, M. (2002). Kimya öğretmenliği lisans öğrencilerinin faz dengeleri konusundaki kavram yanılgıları. 5. Ulusal Fen Bilimleri ve Matematik Eğitimi Kongresi, 1, 677-682. Ankara.

Baloğlu Uğurlu, N. (2005). İlköğretim 6. Sinıf Öğrencilerinin Dünya ve Evren Konusu ile ilgili Kavram Yanılgıları. Gazi University Journal of Gazi Educational Faculty, 25(1), 229-246.

Başer, M., \& Çataloğlu, E. (2005). Kavram Değişimi Yöntemine Dayalı Öğretimin Öğrencilerin Isı ve Sıcaklık Konusundaki "Yanlış Kavramlar"ının Giderilmesindeki Etkisi. H U Journal of Education, 29, 43-52.

Başer, M., \& Geban, Ö. (2007). Effect of instruction based on conceptual change activities on students' understanding of static electricity concepts. Research in Science \& Technological Education, 25(2), 243-267. http://dx.doi.org/10.1080/02635140701250857

Ben-Zvi, R., Eylon, B., \& Silberstein, J. (1986). Is an atom of copper malleable? Journal of Chemical Education, 63, 64-66. http://dx.doi.org/10.1021/ed063p64

Birinci Konur, K., \& Ayas, A. (2008). Sınıf öğretmeni adaylarının bazı kimya kavramlarını anlama seviyeleri. Kastamonu Ĕ̈itim Dergisi, 16(1), 83-90.

Boo, H. K. (2006). Primary science assessment item setters' misconceptions concerning the state changes of waters. Asia-Pacific Forum on Science Learning and Teaching, 7, 1.

Boz, N., \& Boz, Y. (2011). Prospective Chemistry Teachers' Awareness of Students' Alternative Conceptions. Journal of Turkish Science Education, 8(4), 29-42.

Boz, Y. (2005). İlköğretim İkinci Kademe ve Ortaöğretim Öğrencilerinin Yoğunlaşma Konusundaki Kavram Yanılgiları. Hacettepe University Journal of Education, 28, 48-54.

Bozkurt, O., \& Cansüngü Koray, Ö. (2002). İlköğretim Öğrencilerinin Çevre Eğitiminde Sera Etkisi ile ilgili Kavram Yanılgiları. Hacettepe University Journal of Education, 23, 67-73.

Buluş Kırıkkaya, E., \& Güllü, D. (2008). Fifth Grade Students' Misconceptions about Heat - Temperature and Evaporation-Boiling. Elementary Education Online, 7(1), 15-27. Retrieved from http://ilkogretim-online.org.tr

Büyüköztürk, S., Çakmak, E. K., Akgün, Ö. E., Karadeniz, S., \& Demirel, F. (2008). Bilimsel Araştırma Yöntemleri. Ankara: Pegem Akademi (1. bask1).

Çakıcı, Y. (2005). Exploring Turkish upper primary level pupils' understanding of digestion. International Journal of Science Education, 27(1), 79-100. http://dx.doi.org/10.1080/0950069032000052036

Çakmakçı, G., Leach, J., \& Donnelly, J. (2006). Students' Ideas about Reaction Rate and its Relationship with Concentration or Pressure. International Journal of Science Education, 28(15), 1795-1815. http://dx.doi.org/10.1080/09500690600823490

Çalık, M., \& Ayas, A. (2005). 7.-10. sınıf öğrencilerinin seçilen çözelti kavramlarıyla ilgili anlamalarının farklı karışımlar üzerinde incelenmesi. Gazi Üniversitesi Türk Eğitim Bilimleri Dergisi, 3(3), 329-349.

Çalık, M., Ayas, A., \& Ünal, S. (2006). Çözünme Kavramıyla ilgili Öğrenci Kavramalarının Tespiti: Bir Yaşlar Arası Karşılaştırma Çalışması. Gazi Üniversitesi Türk Ĕgitim Bilimleri Dergisi, 4(3), 309-322.

Canpolat, N., Pınarbaşı, T., Bayrakçeken, S., \& Geban, Ö. (2004). Kimyadaki bazı yaygın yanlış kavramlar. $G \ddot{U}$, Gazi University Journal of Gazi Educational Faculty, 24, 135-146.

Çepni, S. (2001). Araştırma ve Proje Çalışmalarına Giriş. Trabzon: Erol Ofset Matbaacılık.

Çetingül, P. İ., \& Geban, Ö. (2005). Understanding of Acid-Base Concept by Using Conceptual Change Approach. Hacettepe University Journal of Education, 29, 69-74.

Çıldır, I., \& Şen, A. İ. (2006). Lise Öğrencilerinin Elektrik Akımı Konusundaki Kavram Yanılgılarının Kavram Haritalariyla Belirlenmesi. Hacettepe University Journal of Education, 30, 92-101.

Çoştu, B., Ayas, A., \& Ünal, S. (2007). Kavram yanılgıları ve olası nedenleri: Kaynama kavramı. Kastamonu Ë̆itim Dergisi, 15(1), 123-136.

Demirci, N., \& Efe, S. (2007). İlköğretim Öğrencilerinin Ses Konusundaki Kavram Yanılgılarının Belirlenmesi. Necatibey Ĕgitim Fakültesi Elektronik Fen ve Matematik Ĕgitimi Dergisi, 1(1), 23-56. 
Driver R., \& Easley J. (1978). Pupils and paradigms: a review of literature related to concept development in

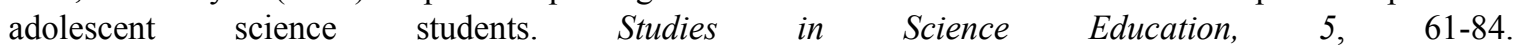
http://dx.doi.org/10.1080/03057267808559857

Driver, R., Guesne, E., \& Tiberghien, A. (1985). Children's Ideas in Science. Milton Keynes, England: Open University Press.

Duit, R., \& Treagust, D. F. (2003). Conceptual change: A powerful framework for improving science teaching and learning. International Journal of Science Education, 25(6), 671-688. http://dx.doi.org/10.1080/09500690305016

Erdem, E., Yılmaz, A., Atav, E., \& Gücüm, B. (2004). Öğrencilerin "madde” konusunu anlama düzeyleri, kavram yanılgıları, fen bilgisine karşı tutumları ve mantıksal düşünme düzeylerinin araştırılması. Hacettepe University Journal of Education, 27, 74-82.

Fensham, P. J., Garrard, J., \& West, L. W. (1981). The use of cognitive mapping in teaching and learning strategies. Research in Science Education, 11, 121-129. http://dx.doi.org/10.1007/BF02356775

Geban, Ö., \& Bayır, G. (2000). Effect of Conceptual Change Approach on Students' Understanding of Chemical Change and Conservation of Matter. Hacettepe University Journal of Education, 19, 79-84.

Gilbert, J. K., \& Swift D. J. (1985). Towards a Lakatosian analysis of the Piagetian and the alternative conceptions research programs. Science Education, 69, 681-696. http://dx.doi.org/10.1002/sce.3730690510

Gilbert, J. K., Osborne R. J., \& Fensham P. J. (1982). Children's science and its consequences for teaching. Science Education, 66, 623-633. http://dx.doi.org/10.1002/sce.3730660412

Gödek Altuk, Y., \& Kaya, V. H. (2011). Kavram Yanılgılarını Tespit Etme Konusunda Fen Bilgisi Öğretmen Adaylarını Bilinçlendirme Üzerine Bir Çalışma, I. Uluslararası Eğitim Programları ve Öğretim Kongresi, Anadolu Üniversitesi, Eskişehir.

Gödek, Y. (1997). Models and Explaining dissolving. Unpublished MSc thesis, University of Reading.

Gödek, Y. (2004). Fen bilgisi öğretmen adaylarının çözünme kavramı hakkındaki düşünceleri, VI. Ulusal Fen Bilimleri ve Matematik Eğitimi Kongresi (UFBMEK-6), Marmara Üniversitesi Atatürk Eğitim Fakültesi, İstanbul.

Gregoire, M. (2003). Is it challenge or a threat: A dual-process model of teachers' cognition and appraisal processes during conceptual change. Educational Psychology Review, 15(2), 147-179. http://dx.doi.org/10.1023/A:1023477131081

Griffiths, A. K., \& Preston, K. R. (1992). Grade-12 students' misconceptions relating to fundamental characteristics of atoms and molecules. Journal of Research in Science Teaching, 29(6), 611-628. http://dx.doi.org/10.1002/tea.3660290609

Gunstone, R. (1988). Learners in science education. In P. Fensham (Ed.), Development and dilemmas in science education (pp. 73-95). London: Falmer Press.

Haidar, A. H., \& Abraham, M. R. (1991). A comparison of applied and theoretical knowledge of concepts based on the particulate nature of matter. Journal of Research in Science Teaching, 28, 919-938.

Helm, H. (1980). Misconceptions in physics amongst South African students. Physics Education, 15, 92-97. http://dx.doi.org/10.1088/0031-9120/15/2/308

Hırça, N., Çalık, M., \& Akdeniz, F. (2008). Investigating Grade 8 Students' Conceptions of 'Energy' and Related Concepts. Journal of Turkish Science Education, 5(1), 75-87.

Janiuk, R. M. (1993). The process of learning chemistry: A review of the studies. Journal of Chemical Education, 70(10), 828. http://dx.doi.org/10.1021/ed070p828

Kaptan, F. (1998). Fen öğretiminde kavram haritası yönteminin kullanılması. Hacettepe University Journal of Education, 14, 95-99.

Karaer, H. (2007). Sınıf öğretmeni adaylarının madde konusundaki bazı kavramların anlaşılma düzeyleri ile kavram yanılgılarının belirlenmesi ve bazı değişkenler açısından incelenmesi. Kastamonu Eğitim Dergisi, 15(1), 199-210.

Karamustafaoğlu, S., \& Ayas, A. (2005). Öğrencilerin 'metal, ametal, yarı-metal ve alaşım' kavramlarını anlama düzeylerinin karşılaştırılması. Journal of National Education, 33, 166. 
Kaya, V. H., \& Gödek Altuk, Y. (2010). 'İlköğretim Öğrencilerinin Basit Elektrik Devresi konusu ile ilgili Kavram Yanılgıları', 1. Ulusal Eğitim Programları ve Öğretim Kongresi, Balıkesir Üniversitesi Necatibey Eğitim Fakültesi ve Eğitim Programları ve Öğretim Derneği, Balıkesir.

Koray, Ö., Akyaz, N., \& Köksal, M. S. (2007). Lise Öğrencilerinin “Çözünürlük” Konusunda Günlük Yaşamla İlgili Olaylarda Gözlenen Kavram Yanılgıları. Kastamonu Ĕgitim Dergisi, 15(1), 241-250.

Koray, Ö., Özdemir, M., \& Tatar, N. (2005). İlköğretim Öğrencilerinin "Birimler" Hakkında Sahip Oldukları Kavram Yanılgıları: Kütle ve Ağırlık Örneği. İlköğretim Online, 4(2), 24-31. Retrieved from http://ilkogretim-online.org.tr

Krajcik, J. S. (1991). Developing students' understanding of chemical concepts. In R. H. Y. S. M. Glynn, \& B. K Britton (Ed.), The psychology of learning science: International perspective on the psychological foundations of technology-based learning environments (pp. 117-145). Hillsdale, NJ: Erlbaum

Küçük, M. (2005). Farklı Öğrenim Seviyelerindeki Öğrencilerin ve Fen Bilgisi Öğretmen Adaylarının Yerçekimi Kuvveti Hakkında Sahip Oldukları Kavramların İncelenmesi. Journal of Turkish Science Education, 2(1), $32-45$.

Küçüközer, H. (2003). Lise I Öğrencilerinin Basit Elektrik Devreleri Konusuyla ilgili Kavram Yanılgıları. Hacettepe University Journal of Education, 25, 142-148.

Küçüközer, H., \& Kocakülah, S. (2007). Secondary School Students' Misconceptions about Simple Electric Circuits. Journal of Turkish Science Education, 4(1), 101-115.

Kurt, Ş., \& Akdeniz, A. R. (2004). Öğretmen Adaylarının Kuvvet Kavramı ile ilgili Yanılgılarını Gidermede Keşfedici Laboratuar Modelinin Etkisi. Hacettepe University Journal of Education, 27, 196-205.

Lawson, A. E., \& Thompson, L. D. (1988). Formal reasoning ability and misconceptions concerning genetics and natural selection. Journal of Research in Science Teaching, 25, 733-746. http://dx.doi.org/10.1002/tea.3660250904

Morgil, İ., Erdem, E., \& Yılmaz, A. (2003). Kimya eğitiminde kavram yanılgıları. Hacettepe University Journal of Education, 25, 246-255.

Özay, E., \& Öztaş, H. (2003). Secondary students' interpretations of photosynthesis and plant nutrition. Journal of Biology Education, 37(2), 68-70. http://dx.doi.org/10.1080/00219266.2003.9655853

Özmen, H., \& Ayas, A. (2003). Students' Difficulties in understanding of the Conservation of matter in Open and closed-system chemical reactions. Chemistry Education: Research and Practice, 4(3), 269-290. http://dx.doi.org/10.1039/b3rp90017g

Özmen, H., \& Demircioğlu, G. (2003). Asitler ve Bazlar Konusundaki Öğrenci Yanlış Anlamalarının Değerlendirilmesinde Kavramsal Değişim Metinlerinin Etkisi. Journal of National Education, 159.

Özmen, H., \& Kenan, O. (2007). Determination of the Turkish primary students' views about the particulate nature of matter. Asia-Pacific Forum on Science Learning and Teaching, 8, 1.

Özmen, H., \& Yıldırım, N. (2005). Effect of Work Sheets on Student's Success: Acid and Bases Sample. Journal of Turkish Science Education, 2(2), 124-143.

Öztürk Ürek, R., \& Tarhan, L. (2005). "Kovalent Bağlar” Konusundaki Kavram Yanılgılarının Giderilmesinde Yapılandırmacılığa Dayalı Bir Aktif Öğrenme Uygulaması. Hacettepe University Journal of Education, 28, 168-177.

Pabuçcu, A., \& Geban, Ö. (2006). Remediating Misconceptions Concerning Chemical Bonding Through Conceptual Change Text. Hacettepe University Journal of Education, 30, 184-192.

Posner, G. J., Strike, K. A., Hewson, P. W., \& Gertzog, W. (1982). Accommodation of scientific conception: Toward a theory of conceptual change. Science Education, 66, 211-227. http://dx.doi.org/10.1002/sce.3730660207

Şen, A. İ. (2003). İlköğretim Öğrencilerinin 1şık, görme ve aynalar konusundaki kavram yanılgılarının ve ögrenme zorluklarının incelenmesi. Hacettepe University Journal of Education, 25, 176-185.

Şen, Ş., \& Yılmaz, A. (2012). Erime ve Çözünmeyle İlgili Kavram Yanılgılarının Ontoloji Temelinde İncelenmesi. Amasya Üniversitesi Ĕ̈itim Fakültesi Dergisi, 1(1), 54-72.

Sencar, S., Y1lmaz, E. E., \& Eryılmaz, A. (2001). High School Students' Misconceptions About Simple Electric Circuits. Hacettepe University Journal of Education, 21, 113-120. 
Sepet, A., Yılmaz, A., \& Morgil, İ. (2004). Lise İkinci Sınıf Öğrencilerinin Kimyasal Denge Konusundaki Kavramları Anlama Seviyeleri ve Kavram Yanılgılar1. HU Journal of Education, 26, 148-154.

Singer, J. E., Tal, R. T., \& Wu, H. K. (2003). Using Multiple Representations to Support Urban Middle School Students Understanding the Particular Nature of Matter. School Science and Mathematics, 103(1), 28-44. http://dx.doi.org/10.1111/j.1949-8594.2003.tb18111.x

Sirhan, G. (2007). Learning Difficulties in Chemistry: An Overview. Journal of Turkish Science Education, 4(2), $2-20$.

Strike, K. A., \& Posner, G. J. (1992). A revisionist theory of conceptual change. In Duschl, R. A., \& Hamilton, R. J. (Eds.), Philosophy of Science, Cognitive Psychology, and Educational Theory and Practice (pp. 147-176). Albany: State University of New York Press.

Taber, K. S. (2001). Building the structural concepts of chemistry: Some considerations from educational research. Chemistry Education: Research and Practice in Europe, 2(2), 123-158. http://dx.doi.org/10.1039/b1rp90014e

Tatar, N., \& Cansüngü Koray, Ö. (2005). İlköğretim Sekizinci Sınıf Öğrencilerinin “Genetik” Ünitesi Hakkındaki Kavram Yanılgılarının Belirlenmesi. Kastamonu Eğitim Dergisi, 13(2), 415-426.

Tekkaya, C. (2003). Remediating High School Students' Misconceptions Concerning Diffusion and Osmosis through Concept Mapping and Conceptual Change Text. Research in Science \& Technological Education, 21(1), 5-16. http://dx.doi.org/10.1080/02635140308340

Tekkaya, C., \& Balcı, S. (2003). Öğrencilerin Fotosentez ve Bitkilerde Solunum Konularındaki Kavram Yanılgılarının Saptanması. Hacettepe University Journal of Education, 24, 101-107.

Tezcan, H., \& Bilgin, E. (2004). Liselerde Çözünürlük Konusunun Öğretiminde Laboratuvar Yönteminin ve Bazı Faktörlerin Öğrenci Başarısına Etkileri. Journal of Gazi Educational Faculty, 24(3), 175-191.

Tezcan, H., \& Salmaz, Ç. (2005). Atomun Yapısının Kavratılmasında ve Yanlış Kavramaların Giderilmesinde Bütünleştirici ve Geleneksel Öğretim Yöntemlerinin Etkileri. Journal of Gazi Educational Faculty, 25(1), 41-54.

Tezcan, H., \& Yılmazel, S. (2004). Lise Öğrencilerinin Çözünürlük Konusundaki Kavram Yanılgılarının Tespiti ve Giderilmesi Konusunda Yöntemlerin ve Diğer Bazı Etkenlerin Araştırılması. Gazi Üniversitesi Türk Ĕgitim Bilimleri Dergisi, 2(3), 323-340.

Topçu, M. S., \& Şahin-Pekmez, E. (2009). Turkish Middle School Students' Difficulties in Learning Genetic Concepts. Journal of Turkish Science Education, 6(2), 55-62.

Treagust, D. F. (1988). Development and use of diagnostic tests to evaluate students. Misconceptions in science. International Journal of Science Education, 10, 159-169. http://dx.doi.org/10.1080/0950069880100204

Tsaparlis, G. (1997). Atomic orbitals, molecular orbitals and related concepts: Conceptual difficulties among chemistry students. Research in Science Education, 27, 271-287. http://dx.doi.org/10.1007/BF02461321

Tunç, T., Akçam, H. K., \& Dökme, İ. (2011). Üç Aşamalı Sorularla Sınıf Öğretmeni Adaylarının Bazı Temel Fen Kavramları Hakkında Sahip Oldukları Kavram Yanılgıları. Journal of Gazi Educational Faculty, 31(2), 817-842.

Türkmen, L., Çardak, O., \& Dikmenli, M. (2005). Lise 1 Biyoloji Dersi Alan Öğrencilerin Canlıların Çeşitliliği ve Sınıflandırılmasıyla ilgili Kavram Yanılgılarının Belirlenmesi ve Kavram Haritası Yardımıyla Değiştirilmesi. Journal of Gazi Educational Faculty, 25(1),155-168.

Üce, M., \& Sarıçayır, H. (2002). Üniversite 1. Sınıf Genel Kimya Dersinde Asit-Baz Konusunun Öğretiminde Kavramsal Değişim Metinleri Ve Kavram Haritalarının Kullanılması. Atatürk Eğitim Fakültesi Eğitim Bilimleri Dergisi, 16, 163-170.

Ünal Çoban, G., Aktamış, H., \& Ergin, Ö. (2007). İlköğretim 8. Sınıf Öğrencilerinin Enerjiyle İlgili Görüşleri. Kastamonu Eğitim Dergisi, 15(1), 175-184.

Ünal, S., Coştu, B., \& Ayas, A. (2010). Secondary School Students' Misconceptions of Covalent Bonding. Journal of Turkish Science Education, 7(2), 3-29.

Watts M. (1983). A study of schoolchildren's alternative frameworks of the concept of force. European Journal of Science Education, 5, 217-230. http://dx.doi.org/10.1080/0140528830050209 
Yalçın, A., \& Kılıç, Z. (2005). Öğrencilerin Yanlış Kavramaları ve Ders Kitaplarının Yanlış Kavramalara Etkisi Örnek Konu: Radyoaktivite. Journal of Gazi Educational Faculty, 25(3), 125-141.

Yıldırım, H. İ., Yalçın, N., Şensoy, Ö., \& Akçay, S. (2008). İlköğretim 6., 7. ve 8. Sınıf Öğrencilerinin Elektrik Akımı Konusunda Sahip Oldukları Kavram Yanılgıları. Kastamonu Eğitim Dergisi, 16(1), 67-82.

Yıldırım, O., Nakiboğlu, C., \& Sinan, O. (2004). Fen Bilgisi Öğretmen Adaylarının Difüzyon İle İlgili Kavram Yanılgıları. BAÜ Fen Bil. Enst. Dergisi, 6(1), 79-99.

Yıldız, A., \& Büyükkasap, E. (2006). Fizik Öğrencilerinin, Kuvvet ve Hareket Konusundaki Kavram Yanılgıları ve Öğretim Elemanlarını Bu Konudaki Tahminleri. Hacettepe University Journal of Education, 30, 268-277.

Yürük, N., \& Çakır, Ö. S. (2000). Lise Öğrencilerinde Oksijenli ve Oksijensiz Solunum Konusunda Görülen Kavram Yanılgılarının Saptanması. Hacettepe University Journal of Education, 18, 185-191.

\section{Questionnaire}

1. When we look around, there are some substances which are solid, liquid or gas.

a) Please identify the states of matter of the substances in I, II and III (chalk, petrol, and water vapor)

b) Please explain the reason of your answer carefully.

2. "Substances such as, ice, water, water vapor have a mass and they are in different states at room temperature".

a) Please identify the states of these substances at room temperature $25^{\circ} \mathrm{C}$ and $1 \mathrm{~atm}$.

b) Please explain the reason of your answer carefully.

3. "Substances such as, ice, water, water vapor have a mass and they are in different states at $0{ }^{\circ} \mathrm{C}$ and $1 \mathrm{~atm} . "$

a) Please identify the states of these substances at $0{ }^{\circ} \mathrm{C}$ and $1 \mathrm{~atm}$.

b) Please explain the reason of your answer carefully.

4. "Each substance in nature may exist in solid, liquid and gas states. At room temperature $25{ }^{\circ} \mathrm{C}$ and $1 \mathrm{~atm}$. substances can be solid, liquid or gas".

a) Please explain the reasons why some substances are solid, some liquid and some gas.

b) Please explain the reason of your answer carefully.

5. "Every particle of a matter has its unique properties. At room temperature, when the attraction force between the particles is large enough to be overcome by the energy taken from the environment",

a) Please identify the state of a matter

b) Please explain the reason of your answer carefully.

6. "When the attraction force of the particles was weakened by the energy taken from the environment, and the spaces between the particles are greater",

a) Please identify the state of the matter

b) Please explain the reason of your answer carefully.

7. "When the attraction force of the particles has been overcome by the energy taken from the environment whereby there is no relation between the particles",

a) Please identify the state of the matter

b) Please explain the reason of your answer carefully.

8. Is it right to assert that "the substances are solid, liquid or gas, without specifying their temperature and pressure"? Please explain the reason of your answer carefully.

9. Is it right to make a distinction between solid, liquid and gas substances? Please explain the reason of your answer carefully.

10. "The properties of the state of a substance are the properties of the particles aligning together".

a) Is this statement correct?

b) Please explain the reason of your answer carefully. 
11. The figure shows the particulate structure of a solid substance. Please draw the particulate structures of this substance in liquid and gas states.

12. "A solid substance is being heated in a closed container. Accordingly, the state of the substance changes". During this process,

a) Is there any change in the number of particles? Please explain the reason of your answer carefully.

b) Is there any change in the size of particles? Please explain the reason of your answer carefully.

13. Please classify the substances (glass, sponge, salt, sugar, smoke, water vapor, cologne, ink, iron, aluminum, milk, air, chalk, soil) as solid, liquid or gas at room temperature $\left(25^{0} \mathrm{C}\right)$ and pressure of 1 atmosphere. Please explain the reason of your answer carefully. 